\title{
ANALISIS PENDAPATAN USAHA IKAN MAS SISTEM KERAMBA JARING APUNG DAN PEMASARANNYA DI KABUPATEN SIMALUNGUN
}

\author{
Bambang Sumantri ${ }^{1}$ \\ Sriyoto ${ }^{1}$ \\ Sumanti Maria P2 \\ 1 Staf Pengajar Jurusan Sosial Ekonomi Pertanian Fak.Pertanian UNIB \\ 2 Alumni Jurusan Sosial Ekonomi Pertanian Fak.Pertanian UNIB
}

\begin{abstract}
This research was aimed at estimating the level of earnings and efficiency obtained by farmer of goldfish with floating net cage system and to investigating the form of marketing channel from floating net cage system from Kelurahan Haranggaol to consumer in Kabanjahe Kabupaten Karo. This research executed in Kelurahan Haranggaol, Kecamatan Haranggaol Horisan, Kabupaten Simalungun, North Sumatera. Fourty samples of goldfish farmer with floating net cage system were slected using simple random sampling method. $R / C$ ratio marjin marketing analysis were used to answer the research purposes. Research resulted farmer carred Rp 107.461.246,06 per season or with $R / C$ ratio of 1,83 . The marketing channel from Kelurahan Haranggaol to consumer in Kabanjahe is identified one channel pattern, that is, compiler merchant to dealers on Kabanjahe and than to Consumer in Kabanjahe. The marjin of marketing is equal to Rp 900 at merchant of compiler and $\mathrm{Rp}$ 1.850 at dealer. Total of marketing marjin is equal to $R p 2.750$.
\end{abstract}

Key Words : income, cyprinus carpio

\section{PENDAHULUAN}

Budidaya ikan sebenarnya sudah lama dikenal secara luas, namun metode yang digunakan masih bersifat tradisional. Untuk meningkatkan produksi ikan perlu kiranya dilakukan pengembangan dibidang metode budidaya ikan ini. Salah satu caranya yaitu dengan teknik budidaya ikan dengan menggunakan keramba jaring apung. Keramba jaring apung adalah wadah berupa kantong jaring yang letaknya terapung di permukaan air. Tujuan budidaya ikan dalam keramba terutama untuk pemanfaatan potensi air sungai atau tepi danau (waduk) yang mempunyai kedalaman terbatas. Keuntungannya adalah pemanfaatan tenaga kerja setempat serta meningkatkan penghasilan dan gizi masyarakat daerah tersebut. Ikan mas (Cyprinus carpio) adalah jenis ikan yang sesuai untuk dibudidayakan dengan sistem keramba ini. Karena selain mudah beradaptasi dengan lingkungan media hidupnya, produksinya pun mempunyai harga yang cukup tinggi di pasar. Di propinsi Sumatera 
Utara, komoditi ikan yang dibudidayakan dalam Keramba Jaring Apung (KJA) terdapat di daerah Simalungun, Karo, Dairi, Toba Samosir dan Tapanuli Utara.

Tabel 1: Potensi Usaha Keramba Jaring Apung di Perairan Danau Toba.

\begin{tabular}{cllc}
\hline No & \multicolumn{1}{c}{ Kabupaten } & \multicolumn{1}{c}{ Nama desa } & Potensi Keramba (Ha) \\
\hline 1 & Simalungun & Tambun Raya & 50 \\
& & Panahatan & 25 \\
& & Harangaol & 100 \\
2 & Karo & Tongging & 80 \\
3 & Dairi & Paropo & 20 \\
4 & Toba Samosir & Ambarita & 8 \\
& & Pangururan & 10 \\
& & Sigapitan & 60 \\
5 & Tapanuli Utara & Muara & 90 \\
\hline & & JUMLAH & 443 \\
\hline
\end{tabular}

Sumber : Lembaga Penelitian dan Pengembangan Masyarakat USU (LPPM USU).

Dari Tabel 1 dapat dilihat bahwa usaha keramba jaring apung yang potensial terdapat di Kabupaten Simalungun dan Desa Haranggaol merupakan desa yang berpotensi paling tinggi untuk pengembangan usaha keramba jaring apung yaitu sebesar $100 \mathrm{Ha}$.Budidaya ikan dalam keramba jaring apung ini mempunyai prospek yang cukup cerah karena selain dapat memenuhi peningkatan gizi masyarakat akan protein hewani, usaha ini juga data meningkatkan pendapatan petani ikan serta dapat pula membuka lapangan kerja baru. Tinggi rendahnya pendapatan petani ikan mas sistem keramba jaring apung dipengaruhi oleh jumlah produksi, harga produksi juga harga dari faktor produksi. Besar kecilnya margin pemasaran juga dapat mempengaruhi besar kecilnya pendapatan petani. Selain peningkatan produksi usahatani, pemasaran juga merupakan salah satu hal yang sangat penting untuk diperhatikan dalam berusahatani. Panjang pendeknya saluran pemasaran juga berpengaruh terhadap besar kecilnya pendapatan petani.

Tulisan ini hanya akan menjelaskan pendapatan petani dalam satu kali proses produksi (enam bulan) yaitu musim panen terakhir yang dilakukan oleh petani ikan mas sistem keramba jaring apung. Sehingga diduga Diduga usaha ikan mas dengan sistem keramba jaring apung di lokasi penelitian sudah menguntungkan dimana nilai $R / C$ ratio $>1$. Pemasaran yang diteliti adalah produksi 
yang merupakan hasil panen terakhir atau panen kedua dalam satu kali proses produksi dan saluran pemasaran yang diteliti, dibatasi pada ikan mas yang dipasarkan di Kabanjahe.

\section{METODE PENELITIAN}

Daerah penelitian ditentukan secara purposive yaitu di Kelurahan Haranggaol, Kecamatan Haranggaol Horisan, Kabupaten Simalungun, Propinsi Sumatera Utara. Alasan pemilihan daerah penelitian ini adalah karena daerah tersebut merupakan daerah yang potensial dalam melakukan kegiatan budidaya ikan mas dengan sistem keramba jaring apung dimana di Kabupaten Simalungun terdapat $175 \mathrm{Ha}$ luas kawasan Danau Toba yang dapat digunakan sebagai media untuk kegiatan budidaya ikan mas sistem keramba jaring apung dan $100 \mathrm{Ha}$ diantaranya terdapat di Kelurahan Haranggaol.Metode penentuan sampel untuk petani ikan mas sistem keramba jaring apung dilakukan secara Simple Random Sampling yaitu sample diambil sedemikian rupa sehingga setiap unit populasi mempunyai kesempatan yang sama untuk dipilih sebagai responden (Nazir, 1988).

Data yang dikumpulkan dalam penelitian ini terdiri dari data primer dan data sekunder. Data primer merupakan data yang diperoleh melalui wawancara langsung dengan menggunakan daftar pertanyaan yang telah dipersiapkan terlebih dahulu yaitu berupa quisioner. Data sekunder adalah data yang diperoleh dalam bentuk yang sudah jadi berupa publikasi yaitu mengenai keadaan umum daerah penelitian seperti profil lokasi penelitian, kependudukan dan lain-lain yang diperoleh melalui lembaga, instansi yang terkait dengan penelitian.

Analisis pendapatan yang digunakan total penerimaan dikurangi total biaya yang dieluarkan dalam usahatani. (Soekartawi, 1995). Sedangkan perbandingan antara penerimaan dan biaya dikenal $\mathrm{R} / \mathrm{C}$. Kriteria yang digunakan adalah $\mathrm{R} / \mathrm{C}$ ratio $>1$, usahatani menguntungkan, $\mathrm{R} / \mathrm{C}$ ratio < 1, usahatani tidak menguntungkan, dan $\mathrm{R} / \mathrm{C}$ ratio $=1$, usahatani tidak menguntungkan dan tidak merugikan. Sementara margin yang diperoleh dari pemasaran hasil usahatani diktehau jan menghitung selisih antara harga di tingkat produsen denganharga yang diterima konsumen.

\section{HASIL DAN PEMBAHASAN}

\section{Struktur Biaya Usaha Ikan Mas Sistem Keramba Jaring Apung}


Peralatan dalam usahatani yang tergolong dalam biaya tetap dalam usaha ikan mas sistem keramba jaring apung adalah peralatan untuk pembuatan keramba dan peralatan lain yang dibutuhkan dalam melakukan usaha ikan mas sistem keramba jaring apung seperti perahu, alat dayung, jala tangan dan ember. Rata-rata biaya penyusutan untuk semua alat yang digunakan dalam usaha ikan mas dapat dilihat pada Tabel 2.

Tabel 2. Rata-rata biaya penyusutan usaha ikan mas sistem keramba jaring apung di Kelurahan Haranggaol.

\begin{tabular}{ccc}
\hline No & Jenis Alat & Nilai (Rp/MP) \\
\hline 1 & Keramba & $2.398 .005,635$ \\
2 & Perahu & $50.809,895$ \\
3 & Dayung & $6.606,25$ \\
4 & Jala tangan & $24.068,75$ \\
5 & Ember & $2.648,125$ \\
6 & Pondok & $233.687,5$ \\
\hline Jumlah & & $2.715 .826,155$ \\
\hline
\end{tabular}

Berdasarkan Tabel 2 dapat dilihat bahwa biaya penyusutan untuk usaha ikan mas sistem keramba jaring apung sebesar 2.482.138,655 rupiah untuk satu kali proses produksi yaitu selama enam bulan. Biaya penyusutan yang paling tinggi adalah biaya penyusutan keramba yaitu sebesar 2.398.005,635 rupiah untuk satu kali proses produksi. Biaya penyusutan keramba ini merupakan biaya yang paling tinggi bila dibandingkan dengan biaya penyusutan peralatan yang lain karena dalam pembuatan keramba ini dibutuhkan banyak peralatan lain seperti drum, jangkar, jaring dan lain-lain. Seperti halnya usahatani lain, usahatani ikan mas sistem keramba jaring apung juga menggunakan berbagai faktor produksi. Faktor-faktor produksi tersebut diantaranya adalah bibit, pakan pokok, pakan tambahan dan tenaga kerja. Penggunaan faktor-faktor produksi tersebut dapat dilihat pada Tabel 3.

Tabel 3. Rata-rata Biaya Variabel Usaha Ikan Mas sistem Keramba Jaring Apung di Kelurahan Haranggaol per Musim Panen.

\begin{tabular}{|c|c|c|c|}
\hline \multirow[t]{2}{*}{ No } & \multirow[t]{2}{*}{ Variabel } & \multicolumn{2}{|c|}{ Per Musim panen } \\
\hline & & Jumlah & Biaya $(\mathrm{Rp})$ \\
\hline 1 & Bibit & 46.750 ekor & 22.946 .875 \\
\hline 2 & Pakan: & & \\
\hline & - $\quad$ Pelet (Pokok) & 595 sak & 96.897 .375 \\
\hline & - Sawi (Tambahan) & 382,75 karung & 1.249 .500 \\
\hline
\end{tabular}

$20 \quad$ AGRISEP Vol. 4 No 1 September 2005: 17 - 27 


\begin{tabular}{cllc}
\hline 3 & - $\begin{array}{c}\text { Jagung (Tambahan) } \\
\text { Pemeliharaan }\end{array}$ & $1.416,25 \mathrm{Kg}$ & 1.799 .375 \\
4 & & 180.000 \\
& Keramba & & \\
& Tenaga kerja: & 104.000 \\
& - TKDK: & $5,20 \mathrm{HOK}$ & $3.306,88$ \\
- Pemeliharaan keramba & $0,17 \mathrm{HOK}$ & 3.903 .750 \\
- Penebaran ikan & 195,19 HOK & $129.603 .566,44$ \\
\hline
\end{tabular}

Berdasarkan Tabel 3 dapat dilihat bahwa jumlah bibit yang ditebar oleh petani usaha ikan mas sistem keramba jaring apung rata-rata 46.750 ekor untuk satu kali proses produksi, dengan jumlah bibit untuk tiap unit keramba sebanyak 4500-5000 ekor. Harga bibit ikan mas rata-rata 493 dalam rupiah dan total biaya yang dikeluarkan oleh petani responden ikan mas sistem keramba jaring apung sebanyak 22.946.875 rupiah untuk satu kali musim panen. Menurut penelitian Tomi (2003), rata-rata biaya bibit untuk petani kelompok sebesar 765.417 rupiah per musim panen. Adanya perbedaan biaya bibit untuk setiap usaha ikan mas sistem keramba jaring apung dipengaruhi oleh jumlah bibit ikan mas yang dipelihara dalam tiap musim panen, dimana semakin banyak jumlah bibit ikan mas yang ditebar dalam satu musim panen akan mengakibatkan biaya yang dikeluarkan untuk bibit ikan mas tersebut juga akan semakin besar.

Jumlah kebutuhan pelet rata-rata petani dalam satu kali musim panen yaitu sebanyak 595 sak, dengan berat $50 \mathrm{Kg}$ untuk tiap sak. Harga rata-rata pelet untuk tiap sak yaitu sebesar 164.550 rupiah. Jadi besarnya biaya yang dikeluarkan petani untuk pelet yaitu sebanyak 96.897.375 rupiah untuk satu kali proses produksi yaitu dalam periode enam bulan. Menurut penelitian Asih (2003), ratarata penggunaan pakan pokok berupa pelet pada usaha keramba yaitu sebesar 158,92 Kg/Ut dengan rata-rata biaya pakan pokok sebesar Rp 476.756,78/Ut, sedangkan menurut penelitian Serda (2004), rata-rata penggunaan pelet pada usaha ikan mas dalam keramba yaitu sebesar 215,54 Kg/MT dan menurut penelitian Soeharno (1999), rata-rata penggunaan pakan ikan untuk usaha keramba jaring apung adalah sebesar $584 \mathrm{Kg}$ untuk satu kali periode produksi.

Selain pakan pokok petani juga memberikan pakan tambahan untuk ikan mas sistem keramba jaring apung yaitu berupa sawi dan jagung. Perbedaan jumlah pakan yang diberikan dipengaruhi oleh jumlah bibit yang ditebar juga umur ikan yang terdapat dalam keramba apung,

$\overline{\text { Pendapatan Usaha Ikan Mas Sistim Keramba Jaring Apung dan Pemasarannya......( Bambang S, Sriyoto, Sumanti) }} 21$ 
dimana semakin besar ikan mas maka akan semakin banyak kebutuhan pakan dari ikan mas tersebut. Rata-rata kebutuhan tenaga kerja usaha ikan mas sistem keramba jaring apung adalah sebanyak 220,46 HOK dengan biaya sebesar Rp 5.789.700 untuk satu kali proses produksi. Menurut penelitian Asih (2003), rata-rata penggunaan tenaga kerja untuk usaha keramba yaitu sebesar 167,45 JOK/Musim dengan biaya sebesar Rp 375.767,23 / Musim. Adanya perbedaan rata-rata penggunaan tenaga kerja ini disebabkan oleh perbedaan jumlah keramba yang dimiliki oleh petani, dimana semakin banyak jumlah keramba yang dimiliki oleh petani maka akan semakin banyak tenaga kerja yang dibutuhkan oleh petani usaha ikan mas sistem keramba jaring apung tersebut.

\section{Pendapatan Usaha Ikan Mas Sistem Keramba Jaring Apung}

Rata-rata produksi usaha ikan mas sistem keramba jaring apung yaitu $13.888,75 \mathrm{Kg}$ pada panen pertama dengan harga rata-rata $\operatorname{Rp} 9.5787,75$ dan produksi sebesar 10.976,25 pada panen kedua dengan harga rata-rata Rp 9.516,25 per kilogram. Rata-rata penerimaan usaha ikan mas sistem keramba jaring apung dapat dilihat pada Tabel 4.

Tabel 4 Rata-rata Produksi, Harga Jual dan Penerimaan Usaha Ikan Mas Sistem Keramba Jaring Apung di Kelurahan Haranggaol.

\begin{tabular}{ccccc}
\hline No & Uraian & Jumlah $(\mathrm{Kg})$ & Harga $(\mathrm{Rp} / \mathrm{Kg})$ & Nilai $(\mathrm{Rp} / \mathrm{MP})$ \\
\hline 1 & Panen I & $13.888,75$ & $9.578,75$ & 132.698 .500 \\
2 & Panen II & $10.976,25$ & $9.516,25$ & $104.366 .312,5$ \\
\hline \multicolumn{5}{c}{ Rata-rata Penerimaan } \\
\hline \multicolumn{5}{c}{}
\end{tabular}

Rata-rata penerimaan yang diperoleh petani dari usaha ikan mas sistem keramba jaring apung adalah sebesar 237.064.812.50 rupiah untuk satu kali proses produksi, data selengkapnya dapat dilihat pada lampiran 7. Menurut Wiadnya (2001) rata-rata penerimaan petani keramba jaring apung adalah sebesar 13.750 .000 rupiah untuk satu kali periode produksi sedangkan menurut penelitian Tomi (2003), rata-rata penerimaan petani kelompok usaha ikan mas sistem keramba sebesar 2.825.167 rupiah per musim panen. Adanya perbedaan jumlah penerimaan usaha ikan mas sistem keramba jaring apung dipengaruhi oleh jumlah produksi yang dihasilkan dalam tiap musim panen, dimana semakin tinggi produksi maka penerimaan juga akan semakin tinggi sedangkan tinggi rendahnya produksi yang dihasilkan dipengaruhi oleh luas dan jumlah keramba yang dimiliki oleh petani ikan mas sistem keramba jaring apung. Pendapatan merupakan selisih antara total 
penerimaan dengan total biaya. Besarnya pendapatan ditentukan oleh besarnya penerimaan dan biaya yang dikeluarkan. Rata-rata pendapatan petani dapat dilihat pada Tabel 5.

Tabel 5. Rata-rata Penerimaan, Biaya dan Pendapatan Petani Usaha Ikan Mas Sistem Keramba Jaring Apung di Kelurahan Haranggaol.

\begin{tabular}{clll}
\hline No & Variabel & Nilai $(\mathrm{Rp} / \mathrm{MP})$ & \\
\hline 1 & Penerimaan & & $237.064 .812,5$ \\
2 & Biaya & $129.603 .566,44$ & \\
3 & Pendapatan & $107.461 .246,06$ & \\
4 & R/C & 1,83 & \\
\hline
\end{tabular}

Besarnya pendapatan petani usaha ikan mas sistem keramba jaring apung rata-rata sebesar 105.920.461,72 rupiah untuk satu kali proses produksi yaitu selama enam bulan. Menurut penelitian Tomi (2003), rata-rata pendapatan usahatani ikan mas dalam keramba untuk petani kelompok yaitu sebesar 988.367 rupiah per musim panen. Perbedaan jumlah pendapatan yang diperoleh petani dalam usahatani ikan mas sistem keramba jaring apung ini dipengaruhi oleh perbedaan jumlah biaya yang dikeluarkan dan perbedaan penerimaan yang diperoleh dalam usaha ikan mas sistem keramba jaring apung dan pendapatan dapat ditingkatkan dengan meminimumkan biaya-biaya yang harus dikorbankan untuk usaha ikan mas sistem keramba jaring apung.

Nilai ratio antara penerimaan dengan seluruh biaya $(R / C$ ratio) usaha ikan mas sistem keramba jaring apung di Kelurahan Haranggaol adalah rata-rata sebesar 1,83. Hal ini menunjukkan bahwa usaha ikan mas sistem keramba jaring apung sudah memberikan keuntungan bagi petani dimana menurut Soekartawi (1995), jika nilai R/C ratio lebih besar dari 1 berarti usahatani tersebut sudah menguntungkan. Nilai R/C sebesar 1,83 berarti bahwa apabila petani mengeluarkan biaya sebesar 1 satuan rupiah maka diharapkan dapat meningkatkan penerimaan sebesar 1,83 satuan rupiah.

\section{Analisis Pemasaran Ikan Mas Sistem Keramba Jaring Apung}

Saluran pemasaran adalah saluran yang digunakan produsen untuk menyalurkan produk dari produsen sampai kepada konsumen. Besarnya jumlah produksi yang diteliti dalam pemasaran 
merupakan hasil produksi usaha ikan mas sistem keramba jaring apung pada panen yang terakhir atau panen kedua. Jumlah penjualan dan pembelian ikan mas di setiap lembaga pemasaran tidak sama. Berdasarkan penelitian di lapangan, saluran ikan mas sistem keramba jaring apung dimulai dari produsen sampai ke konsumen dapat dilihat pada gambar 1:

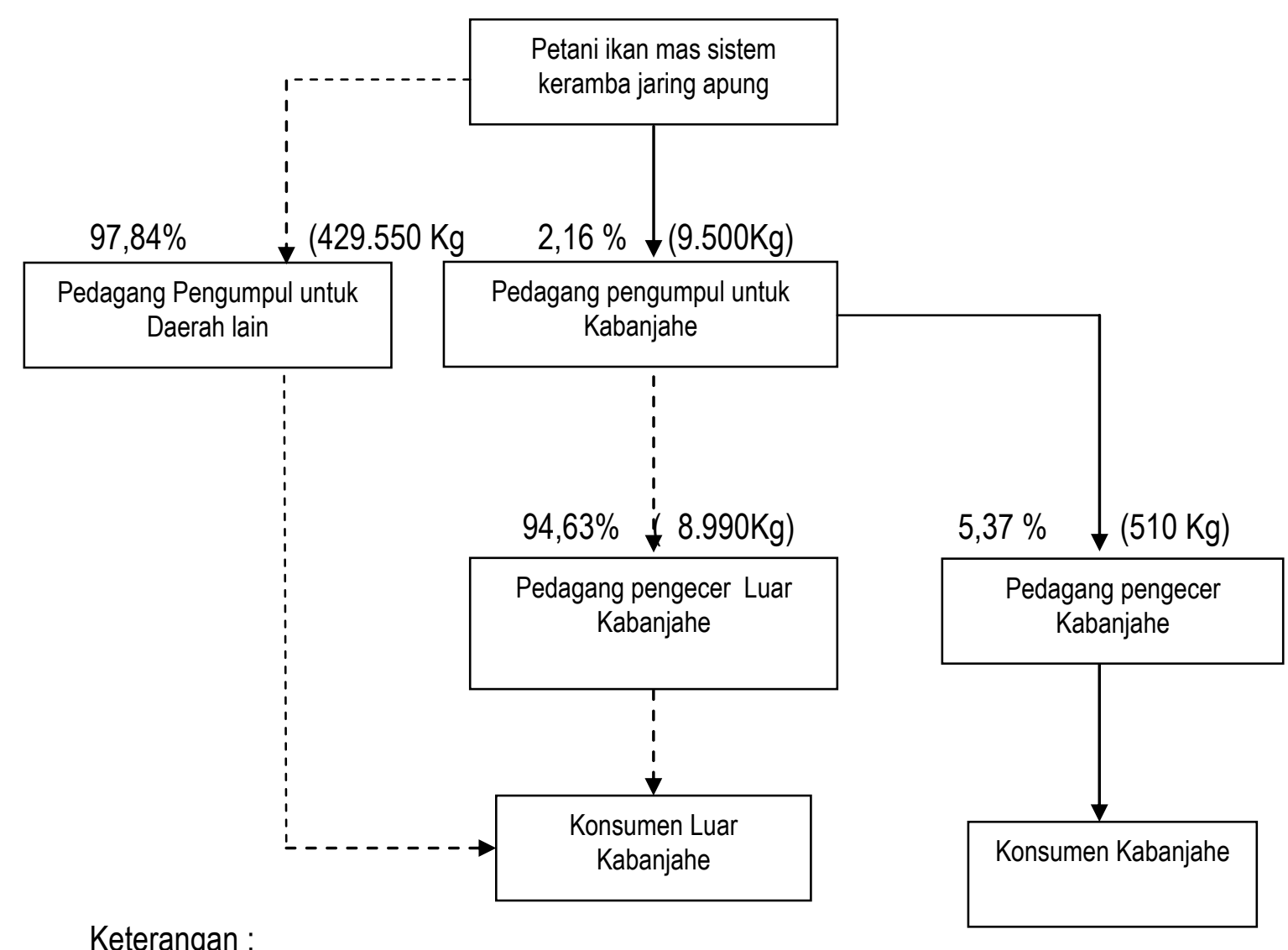

Keterangan :

saluran pemasaran yang diteliti

- . . . . . . $\rightarrow$ saluran pemasaran yang tidak diteliti

Gambar 1. Saluran Pemasaran Ikan Mas dari Kelurahan Haranggaol Sampai ke Kabanjahe.

Marjin pemasaran menggambarkan perbedaan harga yang dibayarkan oleh konsumen akhir dengan harga yang diterima oleh produsen. Yang termasuk kedalam marjin pemasaran adalah biaya pemasaran dan keuntungan pemasaran. 
Tabel 6. Marjin Pemasaran Ikan Mas Sistem Keramba Jaring Apung di Kabanjahe

\begin{tabular}{|c|c|c|c|}
\hline No & Uraian & Jumlah (Rp/Kg) & Share $(\%)$ \\
\hline \multirow[t]{2}{*}{1} & Petani & & \\
\hline & Harga jual & 9.600 & 77,73 \\
\hline \multirow[t]{12}{*}{2} & Pedagang pengumpul & & \\
\hline & a. Harga beli & 9600 & 77,73 \\
\hline & Biaya pemasaran & & \\
\hline & B. kantong & 141,33 & 1,14 \\
\hline & B. tenaga kerja & 16 & 0,13 \\
\hline & B. angkut & 16 & 0,13 \\
\hline & B. oksigen & 7 & 0,06 \\
\hline & B. penyusutan & 0,06 & 0,01 \\
\hline & Total biaya pemasaran & 180,39 & 1,47 \\
\hline & Harga jual & 10.500 & 85,02 \\
\hline & Marjin pemasaran & 900 & 7,29 \\
\hline & Keuntungan & 719,61 & 5,82 \\
\hline \multirow[t]{14}{*}{3} & Pedagang pengecer & & \\
\hline & a. Harga beli & 10.500 & 85,02 \\
\hline & b. Biaya pemasaran & & \\
\hline & - B. kantong & 91,79 & 0,73 \\
\hline & - Sewa kios & 662,5 & 5,36 \\
\hline & - Retribusi & 29,62 & 0,24 \\
\hline & - B. penyusutan & 4,74 & 0,04 \\
\hline & c. Total biaya pemasaran & 788,65 & 6,38 \\
\hline & d. Harga jual & 12.350 & 100 \\
\hline & e. Marjin pemasaran & 1850 & 14,98 \\
\hline & f. Keuntungan & 1061,35 & 8,6 \\
\hline & Total biaya saluran pemasaran & 969,04 & 7,85 \\
\hline & Total marjin pemasaran & 2750 & 14,41 \\
\hline & Total keuntungan & 1780,96 & 22,27 \\
\hline
\end{tabular}




\section{KESIMPULAN DAN SARAN}

\section{Kesimpulan}

Berdasarkan hasil penelitian dapat diambil beberapa kesimpulan sebagai berikut:

1. Rata - rata pendapatan petani ikan mas sistem keramba jaring apung di daerah penelitian selama satu kali proses produksi adalah sebesar Rp. 107.461.246,06/MP serta menguntungkan yang ditunjukkan dengan nilai $R / C$ ratio sebesar 1,83.

2. Saluran pemasaran yang dilewati dalam memasarkan ikan mas sistem keramba jaring apung dari Kelurahan Haranggaol sampai ke Kabanjahe yaitu : petani, pedagang pengumpul pedagang pengecer serta konsumen. Marjin pemasaran ikan mas di daerah penelitian dari petani sebagai produsen sampai ke konsumen adalah sebesar Rp 2750/ Kg.

\section{Saran}

Usaha ikan mas sistem keramba jaring apung menguntungkan, maka usaha tersebut perlu terus dikembangkan. Sehubungan dengan hal tersebut maka petani hendaknya mengelola usaha tersebut dengan intensif sehingga kualitas dan produksi bisa lebih ditingkatkan. Membantu petani dalam meningkatkan pendapatannya maka petani sebaiknya membentuk suatu kelompok petani dan Kelompok Pemasaran Bersama (KPB) yang terdiri dari beberapa kelompok tani. Tugas dan fungsi KPB ini lebih memperkuat posisi tawar menawar petani.

\section{DAFTAR PUSTAKA}

Asih. 2003. Analisis Produksi, Efisiensi dan Marjin Pemasaran Usahatani Ikan Mas (Cyprinus carpio L) Dalam Keramba di Kecamatan Curup Kabupaten Rejang Lebong. Skripsi Fakultas Pertanian. UNIB.

Iskandar, Azhar. 1999. Analisis Fungsi Produksi Usaha Pembesaran Ikan Dalam Kantong Jaring Apung di Perairan Danau Maninjau Propinsi Sumatera Barat. No. 29 Edisi Mei Tahun XI.

Naziir. 1988. Metode Penelitian. Ghalia Indonesia. Jakarta.

Prawirokusumo. 1990. IImu Usahatani. BPFE. Yogyakarta.

Serda. 2004. Analisis Penggunaan Faktor-faktor Produksi Pada Usahatani Ikan Mas (Cyprinus carpio L) dalam Keramba Serta Pemasaran Produknya (Studi Kasus di Desa Tebing Kaning Kecamatan Argamakmur Kabupaten Bengkulu Utara. Skripsi Fakultas Pertanian. UNIB.

26 AGRISEP Vol. 4 No 1 September 2005: 17 - 27 
Soeharno, Suryantoro, Susilo, Supriyono. 1999. Analisis Ekonomi Budaya Ikan Dengan Menggunakan Jala Karamba Apung di Waduk Gajah Mungkur Wonogiri dan Rawapening Salatiga.

Soekartawi. 1995. Prinsip Dasar Manajemen Pemasaran Hasil-hasil Pertanian. Rajawali Pers. Jakarta.

1995. Analisis Usaha Tani.UI Press, Jakarta.

Tomi. 2003. Analisis Pendapatan Usahatani Ikan Mas Dalam Keramba Pada Petani Kelompok dan Petani Bukan Kelompok.(Studi Kasus Di Kecamatan Curup, Kabupaten rejang Lebong). Skripsi Fakultas Ekonomi. UNIB.

Wiadnya, Purwohadijanto, Hariati. 2001. Paket Teknologi Pakan Sebagai Pemacu Pengembangan Agribisnis Ikan Nila Sistem Keramba Jaring Apung. Habitat 12 (2): 